\title{
Forest Zoning Criteria in Conservation Forest: Case Study in Komono Town, Mie Prefecture
}

\author{
Yuki Hirose $^{1}$, Shinji Kawata ${ }^{1}$, Naoto Matsumura ${ }^{1 *}$
}

Abstract: $\quad$ Since 2012, the town of Komono in Mie Prefecture, Japan, has been planning to build an energy circulation system for a sustainable society utilizing forest products or woody biomass. Today, it is necessary to evaluate the current forest conditions in the town of Komono and determine a utilization method for its forest resources. The purpose of this study is to evaluate the current forest conditions in the town of Komono through the lens of forest functions, in other words, services provided by the forests that are highly valued by the public; and to review a forest zoning system method for an effective and sustainable use of the local forest resources. The evaluation standards use data, such as forest structure and management records, as a factor in the evaluation. The result showed that southern areas of the town of Komono had lower evaluation scores compared to the northern and central areas, when the comparison is based on functions of water conservation and mountainous disaster prevention. These results also reveal that the southern areas should be administered preferentially when carrying out forest management activities. Based on the evaluation results and forest zoning system in Mie Prefecture, the forests in the town of Komono were categorized into four new specialized categories which correspond to the forest functions. The study concludes that although there are issues associated with the use of the new approach developed for this study, the methodology is sound, as it can easily be used to produce the desired results.

Keywords: forest function evaluation, forest zoning, GIS, Town of Komono

\section{Introduction}

In recent times, forest management in Japan has taken a tumble down for the worse, towards a state of despair. This can be partly attributed to the implementation of liberal policies associated with timber imports from other countries. Domestic timber prices have fallen drastically as a result of cheap imports. This worsening condition is further compounded by a rise in labour cost, resulting from high economic growth, which in turn has led to a reduction in profit margins for most forestry companies. The result of this is a reduction in investments in forest management activities such as bush removal, intensive silviculture, thinning etc. The dilapidation of forest management in Japan has become so serious that, not only has it affected optimal timber production, but it has also affected other ecosystem services such as water resource management (Kawata and Matsumura, 2006).

Forest management in the town of Komono, in Mie Prefecture, Japan, is a microcosm of what is happening all over Japan. In recent times, there has been a decrease in the number of investments in silviculture or forest management activities, which has negatively led to widespread disturbances such as diseases, insect damages, natural disasters, etc. These problems are projected to worsen with time. The western part of the town of Komono is the Suzuka Quasi-National Park. This park is an important resource, both as a tourist attraction which supports the local economy and as habitat for rare and endangered species.

To address the environmental problems caused by the neglect of forest management activities in the town of Komono, policy makers, since 2012, are planning to build an energy circulation system for a sustainable society. The plan ensures maximum utilization of forest products or woody biomass so as to create a better community. Planning for this future forest and researching the potential for this energy circulation system in the town of Komono, is important for two reasons: 1) to ensure an accurate evaluation of the current forest conditions; and 2) to properly stratify the forest landscape to ensure an effective and sustainable use of the forest resources, the so-called "forest zoning system".

1) The evaluation of values or services provided by forests (also referred to in this paper as forest functions) is based on several factors. This is because most forests in Japan are located

Received Apr. 25, 2017; Accepted Jan. 25, 2018

${ }^{1}$ Mie University, Japan

*Corresponding Author: nma@bio.mie-u.ac.jp 
in mountainous areas which are impacted by various environmental conditions. A study of literature shows that previous studies have used evaluation factors such as vegetation and geographic information to evaluate services provided by forests through field survey (Hokkaido, 2006). Other researchers have employed topographic analysis data using Digital Elevation Model (Ito et al., 2013) and more diversified data consisting of forest structure, practice records, geographic and geological features, and several other environmental factors to evaluate values or services provided by forests (Kohroki, 2003). In this study, we evaluate forest functions, in other words, values or services provided by forests in the town of Komono, as a preparatory analysis based on scientific literature (Wu et al., 2004). Here the authors use data such as forest structure and management records (only by forest register) as factors for evaluation.

2) The forests in Mie Prefecture are classified and zoned into two major forest categories: production forest and environmental forest, on the basis of conditions such as distance from forestry roads (Tsujiuchi, 2005). Based on a concept of forest classification, in 2001, the Forestry Agency established Forestry Basic Law, and Forest and Forestry Basic Plan. In this study we develop a forest zoning system for the town of Komono, using the system that is currently implemented in Mie Prefecture.

Based on the aforementioned, the purpose of this study is to evaluate the current values or services provided by forests (forest functions) in the town of Komono, so that it can serve as a "model region" for Japan. The second objective is to review the method of forest zoning systems for an effective and sustainable use of the local forest resources.

\section{Study Site and Methods}

\subsection{Study site}

The study site is Komono, a town located in the northwestern part of Mie Prefecture, Japan, and on the eastern foothills of the Suzuka Mountains (Figure 1). Komono has a total land area of about 10,701 ha, of which approximately 50.0\% (5,353 ha) is forested (Mie Pref. 2014) (Table 1). The amount of planted forest is approximately $30 \%$, which implies that the forest cover in Komono is primarily, natural forest or old growth. Not much secondary growth or reforestation has been carried out in the town of Komono. The western part of the town is bordered by the Suzuka Quasi-National Park, which attracts many tourists to the town of Komono. The most popular tourist attractions in this area are the hot springs and Mt. Gozaisho. In addition, the forests in this area also have valuable plants and animals such as the star magnolia (Magnolia stellata Maxim.), Japanese serow (Capricornis crispus) on the Red List Ranking of the Ministry of Environment. Hence, the forests in this town play an important role as a tourist attraction, supporting the local economy and as a habitat for sheltering rare and endangered species (Matsumura, 2014).

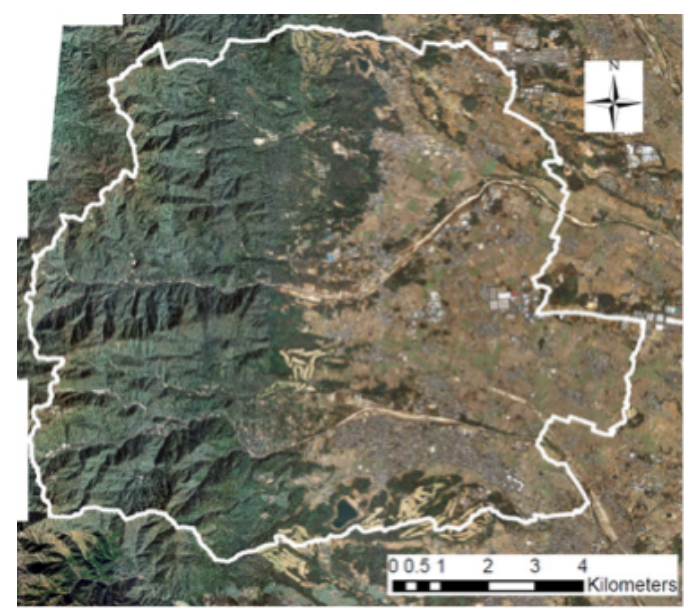

Figure 1. Komono Town, Mie Prefecture in Japan. 
Table 1. Konomo Town land use (Mie Pref. 2014)

\begin{tabular}{lr}
\hline Forest and land use type & Area (ha) \\
\hline Forest Natural & $3,474.6$ \\
Plantation & $1,659.4$ \\
The other & 219.0 \\
\hline Total & $5,353.0$ \\
\hline
\end{tabular}

\subsection{Methods}

\subsubsection{Valuation of environmental services or functions provided by forests}

This study evaluates four environmental services (forest functions) that were identified in the study by Wu et al., (2004). Two of these services or functions are highly valued by the public: "services provided by forests for water conservation", and "services provided by forests to prevent mountainous disaster". The water conservation services in this study is a collective term for two services provided by the forests; one is a flood alleviation service which reduces the peak flow of flood runoff hydrographs and delays peak generation time, and the other is a water conditioning function which adsorbs several chemical substances, including phosphorus, nitrogen, and minerals when rainwater seeps into the soil. The "mountainous disaster prevention service" is a collective term to describe services provided by forests for landslide prevention, and prevention of landslides from collapsing, which is the function of preventing or alleviating erosion phenomena including mudslides, floods, landfalls and surface erosion.

The evaluation method in this study is applied to a "score evaluation method", which is able to evaluate quantitatively, in accordance with the research by Wu et al., (2004). In this research, evaluation factors are selected from analysis between characteristics of the various services or functions provided by forests and an actual result of investigations. The selected factors are those with the highest relationship correlating with each function. The factors provide evaluation standards with comprehensive scores of the functions (Zheng, 1994).

\subsubsection{Procedure for evaluating services or functions provided by forests}

A determination of the evaluation standards requires suitable evaluation factors, as mentioned in section 2.2.1. The standards are determined from elements showing ideal, as well as desirable forest characteristics in exhibiting each function or providing a service.

\section{- Ideal forest exhibiting water conservation function}

The primary condition for being an ideal forest is the existence of forest soil, with well-developed root systems involved in its development. In order to maintain a rich soil layer, the protection of the forest floor by undergrowth vegetation, dead leaves and dead branches is also important, just like a well-developed root system. Tree height can be used as a proxy or a guide to measure the extent of root development system as well as the amount of dead leaves. However, in this study, we use stand age (Forestry Agent, 1991) in place of tree height. As a measure of the state of management of the forest, forest density, tree species and management states are used (Wu et al., 2004). In Wu et al., (2004) crown density is used as a proxy for forest density, however in this study we use individual tree density, which has similar information as forest density, in the 2010 edition of the forest registry.

It is an established fact that the amount of evaporation involved in hydrological balance reaches a peak when forest within a watershed, reaches a certain stand age, and then gradually declines, thereafter (FFPRI, 2000). A decrease in the amount of evaporation can have a negative environmental consequence, when viewed through the lens of potential flood damage. A reduction in evaporation causes the amount of water in the soil to increase and the water retaining ability of the soil to decrease. However, when there is an increase in the amount of evaporation, this can lead to a decrease in river flow rate or a reduction in water resources, within a community watershed, during normal periods. Based on the aforementioned, it can be said that, aging of a stand can have a positive effect on flood alleviation and watershed conservation. This is because as a stand ages, 
the root system becomes well-developed and the amount of litterfall (dead leaves and branches) increases. Taken together, stand age has a rather positive effect on the flood alleviation and enhances watershed conservation functions of the forest.

\section{- Ideal forest exerting mountainous disaster prevention function}

For the purpose of the evaluation of the services provided by forests to prevent mountainous disaster, in other words, mountainous disaster prevention function, the condition of the undergrowth vegetation is used in the evaluation. Undergrowth vegetation is dependent on forest-type; hence, it is necessary to categorize forest-types in the evaluation. The forests exhibiting this function are highly correlated with stand age and density (individual tree).

There can also be a gradient of other factors.

1. Define a weight of the evaluation factors of a function, $\alpha$

2. Define category ratings for each evaluation factor, $\beta$

3. Obtain the category rating for the particular evaluation factor by, $\alpha \times \beta-\gamma$

4. Count $\gamma$ of all evaluation factors, and it is assumed to be evaluation score of the particular function (Tables 2 and 3).

All evaluation standards (Factor, Weight, Category, Rating, Score), except for density, follow the research work in the study of Wu et al., (2004). With respect to density, individual tree density in the forest registers is used differently than the above research, which has four categories: treeless, sparse, moderate, dense. For rating and score, they adopted the same value as crown density, with four categories of density. The evaluation scale is a sub-compartment within $100 \mathrm{~m}$ from forestry roads, including planned roads.

It is impossible, just to compare each service provided by a forest or each forest function appropriately with the calculated evaluation scores. Therefore, the scores of each function or service are standardized and prioritized using a relative scale. A function or service with a higher score is defined as a major function.

Table 2. Standard of water conservation

$\times$ : non-management, $\triangle$ : weeding, improvement cutting, $\bigcirc$ : non-periodic thinning, pruning, $\odot$ : periodic and proper thinning, pruning

\begin{tabular}{|c|c|c|c|c|}
\hline Factor/Weight & Category & & Rating & Score \\
\hline \multirow{7}{*}{$\begin{array}{l}\text { Stand age } \\
\quad / 0.6\end{array}$} & $0-15$ & & 0 & 0 \\
\hline & $16-20$ & & 20 & 12 \\
\hline & $21-30$ & & 50 & 30 \\
\hline & $31-40$ & & 70 & 42 \\
\hline & $41-50$ & & 80 & 48 \\
\hline & $51-70$ & & 90 & 54 \\
\hline & Over 71 & & 100 & 60 \\
\hline \multirow{4}{*}{$\begin{array}{c}\text { Density } \\
/ 0.2\end{array}$} & Treeless & & 0 & 0 \\
\hline & Sparse & & 70 & 14 \\
\hline & Moderate & & 100 & 20 \\
\hline & Dense & & 80 & 16 \\
\hline \multirow{6}{*}{$\begin{array}{c}\text { Management } \\
/ 0.2\end{array}$} & & $x$ & 0 & 0 \\
\hline & Conifer & $\triangle$ & 40 & 8 \\
\hline & & 0 & 70 & 14 \\
\hline & & ( ) & 100 & 20 \\
\hline & Hardwood & $\times \triangle O$ & 50 & 10 \\
\hline & & ○) & 100 & 20 \\
\hline
\end{tabular}


Table 3. Standard of mountainous disaster prevention function $\times$ : non-management, $\triangle$ : weeding, improvement cutting, $\bigcirc$ : non-periodic thinning, pruning, $\odot$ : periodic and proper thinning, pruning

\begin{tabular}{|c|c|c|c|c|}
\hline Forest type & Factor/Weight & Category & Rating & Score \\
\hline \multirow{14}{*}{$\begin{array}{c}\text { Plantation } \\
\text { (Conifer) }\end{array}$} & \multirow{4}{*}{$\begin{array}{l}\text { Stand age } \\
\quad / 0.4\end{array}$} & $0-15$ & 0 & 0 \\
\hline & & $16-30$ & 30 & 12 \\
\hline & & $31-50$ & 70 & 28 \\
\hline & & Over 51 & 100 & 40 \\
\hline & \multirow{4}{*}{$\begin{array}{c}\text { Density } \\
/ 0.2\end{array}$} & Treeless & 0 & 0 \\
\hline & & Sparse & 60 & 12 \\
\hline & & Moderate & 100 & 20 \\
\hline & & Dense & 80 & 16 \\
\hline & \multirow{2}{*}{$\begin{array}{l}\text { Management } \\
/ 0.2 \\
\end{array}$} & $x$ & 0 & 0 \\
\hline & & $\triangle \bigcirc \odot$ & 100 & 20 \\
\hline & \multirow{4}{*}{$\begin{array}{l}\text { Gradient } \\
\quad / 0.2\end{array}$} & Over 31 & 0 & 0 \\
\hline & & $30-21$ & 60 & 12 \\
\hline & & $20-11$ & 80 & 16 \\
\hline & & $0-10$ & 100 & 20 \\
\hline \multirow{12}{*}{$\begin{array}{c}\text { Natural } \\
\text { (Hardwood) }\end{array}$} & \multirow{4}{*}{$\begin{array}{l}\text { Stand age } \\
\quad / 0.6\end{array}$} & $0-15$ & 0 & 0 \\
\hline & & $16-30$ & 60 & 36 \\
\hline & & $31-50$ & 80 & 48 \\
\hline & & Over 51 & 100 & 60 \\
\hline & \multirow{4}{*}{$\begin{array}{c}\text { Density } \\
/ 0.2\end{array}$} & Treeless & 0 & 0 \\
\hline & & Sparse & 70 & 14 \\
\hline & & Moderate & 90 & 18 \\
\hline & & Dense & 100 & 20 \\
\hline & \multirow{4}{*}{$\begin{array}{c}\text { Gradient } \\
\quad / 0.2\end{array}$} & Over 31 & 0 & 0 \\
\hline & & $30-21$ & 60 & 12 \\
\hline & & $20-11$ & 80 & 16 \\
\hline & & $0-10$ & 100 & 20 \\
\hline
\end{tabular}

\subsubsection{Forest zoning system}

The zoning system in Mie Prefecture which is subdivided into a production forest and an environmental forest is further stratified into six categories. Based on the zoning system in Mie Prefecture, in this study, the town of Komono is stratified into four new specialized categories (below), focusing on conservation area, types of forest, and functions. The zoning scale is sub-compartmentalized as in section 2.2.2.

\section{- Production forest}

I. Conservation forest: the focus is to produce timber according to the demand, but also focus on conservation of natural environment.

II. Sustained production forest: the focus is on planned and sustained production of wood and forest products.

\section{- Environmental forest}

III. Water conservation forest - the focus is on improvement of flood alleviation function and the water conditioning function.

IV. Soil conservation forest - the focus is on improvement of the landslide prevention and collapsing landslide prevention function. 


\subsubsection{Procedure of forest zoning system}

First, sub-compartments are classified and zoned into two forest categories, production forest and environmental forest, in accordance with the zoning system in Mie Prefecture. Production forest is plantation forest located in within $400 \mathrm{~m}$ from the forestry road or has undertaken forest management activities, except forests with slopes greater than 45 degrees or protected forest (such as forests in national parks and primeval or historic forests). The other forest category is environmental forest (Tsujiuchi, 2005).

\section{1) Case study of production forest}

When a forest is classified as a production forest, the next step is to classify the forest on the basis of whether the sub-compartment is located in or outside a quasi-national park. In a production forest, it is generally easy to produce timber from a forest because of the proximity from forestry roads; within $400 \mathrm{~m}$, or has a record of forest management. Considering local characteristics of the town of Komono, forest conservation in the national park is important to the local economy. Hence it follows that forests in the national park are designated as conservation forest, and forests outside the national park are designated as sustained production forest (Figure 2).

\section{2) Case of environmental forest}

When a forest is classified as an environmental forest, the next step is to classify the forest on the basis of whether the sub-compartment is located in or outside a protection forest (as defined in the Forest Act). The protection forest is given a priority function because of the high value society places on protection forests. In addition, since the protection forests have a predefined forest management goal, which restricts forest management activities such cutting or changes in landuse (Forestry Agency, 2007), it is important to consider these facts in the zoning system of this study. Although the protection forest has 17 forest types, $96 \%$ of the total protected forests area in the town of Komono, consist of only three forest types; water conservation, landslide prevention, collapsing landslide prevention. In view of this fact, it follows that forests in the protection forest of the water conservation type are designated as the water conservation forest; and forests in the protection forest of the landslide prevention or collapsing landslide prevention type are designated as the soil conservation forest. Forests in the other protection forests or outside the protection forest are classified according to the major function (Figure 2).

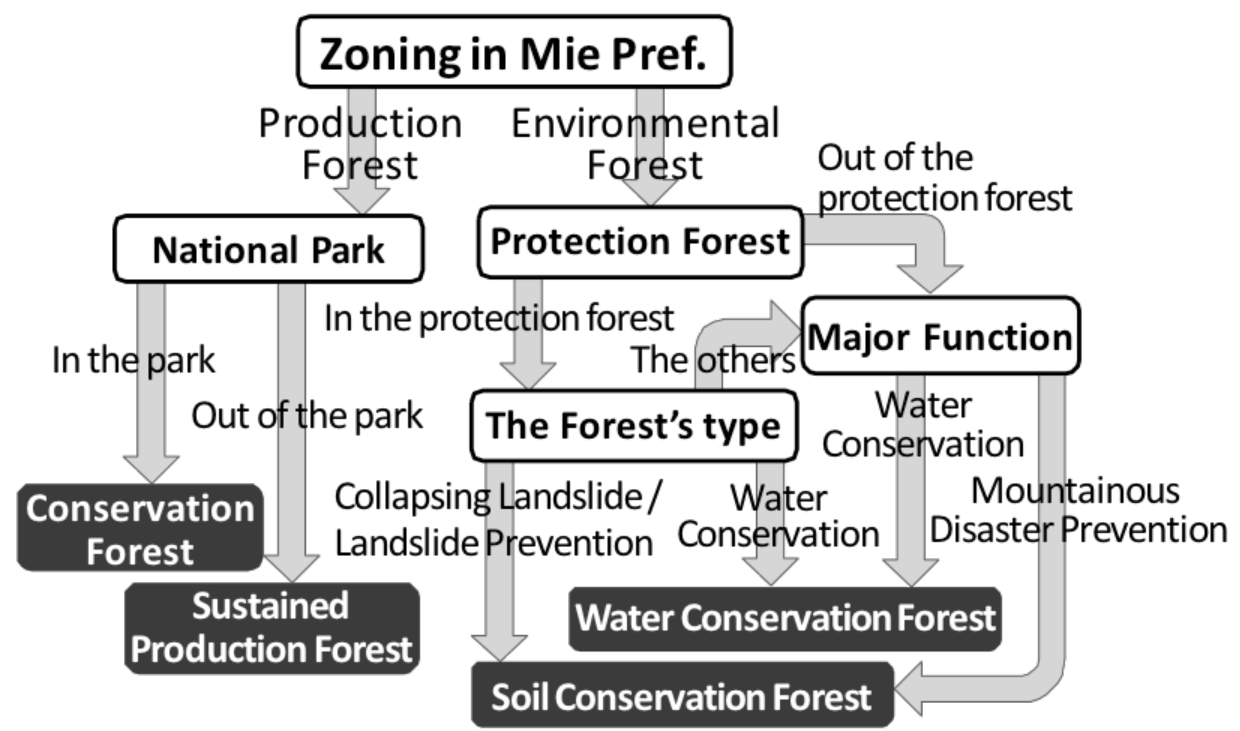

Figure 2. Flow chart of zoning. 


\section{Results and Discussion}

\subsection{Forest function evaluation or evaluation of services provided by forests}

The results from this study show that the southern area of the town of Komono is characterized by lower scores of both functions of water conservation and mountainous disaster prevention compared to the northern or central areas of Komono (Figure 3). The results also reveal that calculation of the evaluation scores confirmed that stand age with the highest weight of the evaluation standards had a smaller dispersion throughout the site, and that the southern area, which had more planted forests, failed to carryout forest management activities, and therefore resulted in reduced scores. For future forest management, it is necessary to manage preferentially in the southern area with lower score. With respect to forest management in Komono, it also revealed that there is a problem of underutilization, as the forests in this area have too much woody residue. About 12,500m3 was produced by past non-commercial thinning practices. It is therefore urgent to haul the woody residue to facilities that can utilize the woody residue and also to undertake forest management activities such as thinning (Matsumura, 2014).

On the other hand, nearly $70 \%$ of the forest area in the town of Komono is covered with natural forests. As a result, it led to high scores in these areas. This is because the average age in the natural forest is about 60 years, which is considered to be the age of a matured forest. Although the plan is to utilize coniferous trees as woody biomass in Komono, future forest management planactivities, including afforestation, should consider natural forests with high scores that have a wide distribution on the site.

With respect to the major function, the results revealed that while there was no great difference in the number of its sub-compartments, between the functions, the forest area of major function with water conservation, was larger than the others (Figure 4). The distribution of the major functions in the mountainous area shows that of the major function with water conservation, concentrations in the headwater or upper stream, is preferable with respect to environmental conservation.
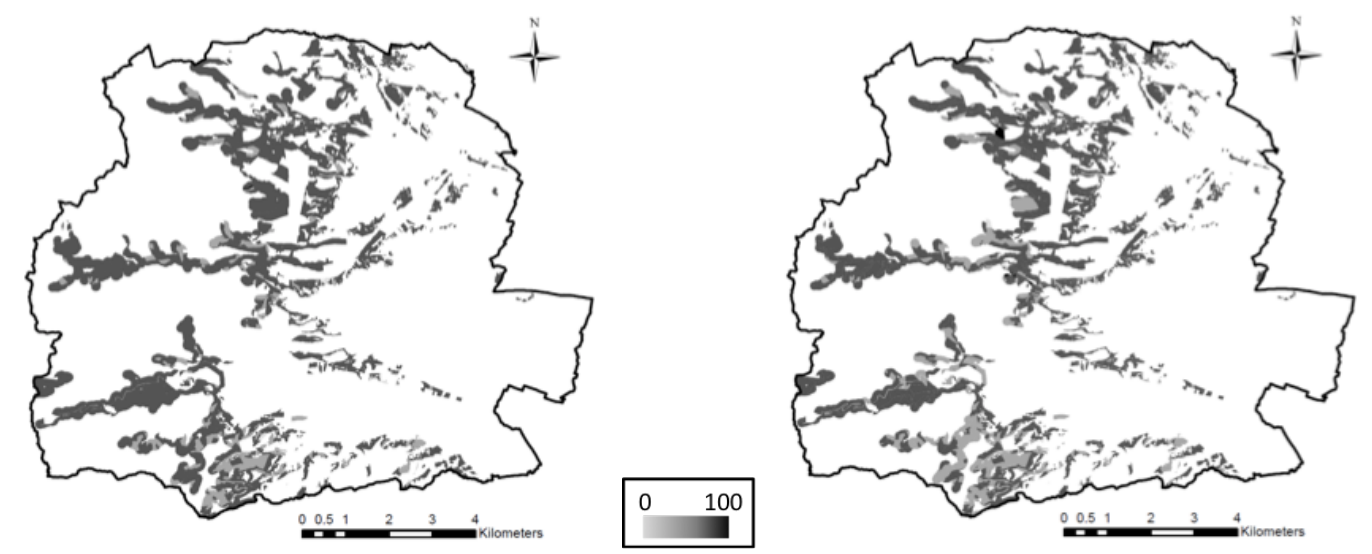

Figure 3. Evaluation results of L: water conservation and R: mountainous disaster prevention.

\subsection{Forest zoning system}

From Figure 5, it can be seen that the sustained production forest has a wide distribution in the southern and central areas, closer to the city center. Considering a forest owners' attitude towards forest management, the current state of forest roads, and experience with past thinning practices, the southern area is considered to be a base area of supplying woody biomass. The results show that although the conservation area was small in size, it played an important role as a buffer zone connecting the sustained forest area with the national park. Judging from most protection forests with water conservation type and the forests with major function of water conservation, (which are determinants in this zoning system), it was observed that, they are placed in the same areas; in headwater streams, and upper streams, where a large number of the water conservation forest are allocated appropriately. The soil conservation forest is distributed mainly at the foothills of the 


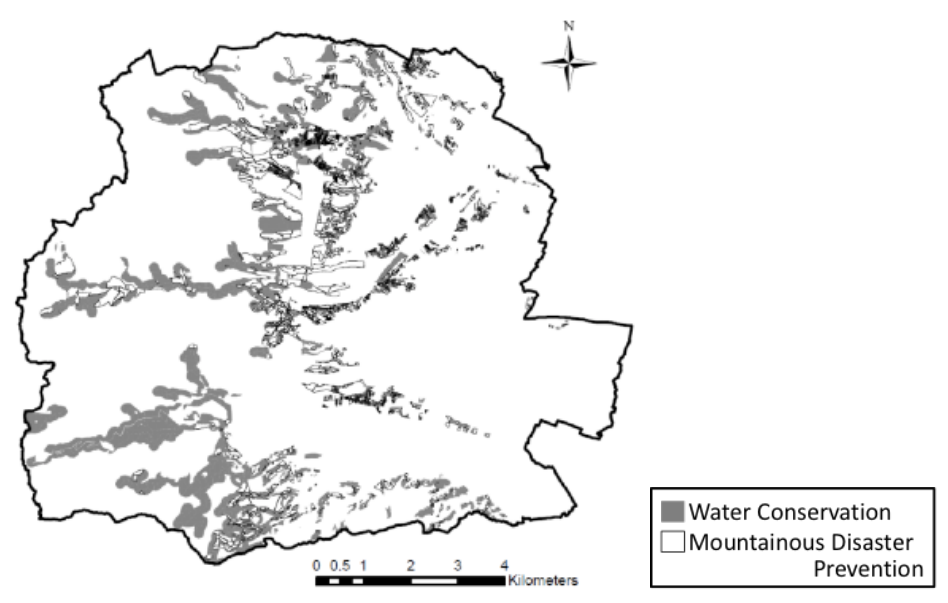

Figure 4. Result of major function.

mountains or deep within. It shows, it mitigates the risks of collapsing landslides on steep sloping lands on mountains and it prevents sediment disaster into the city center.

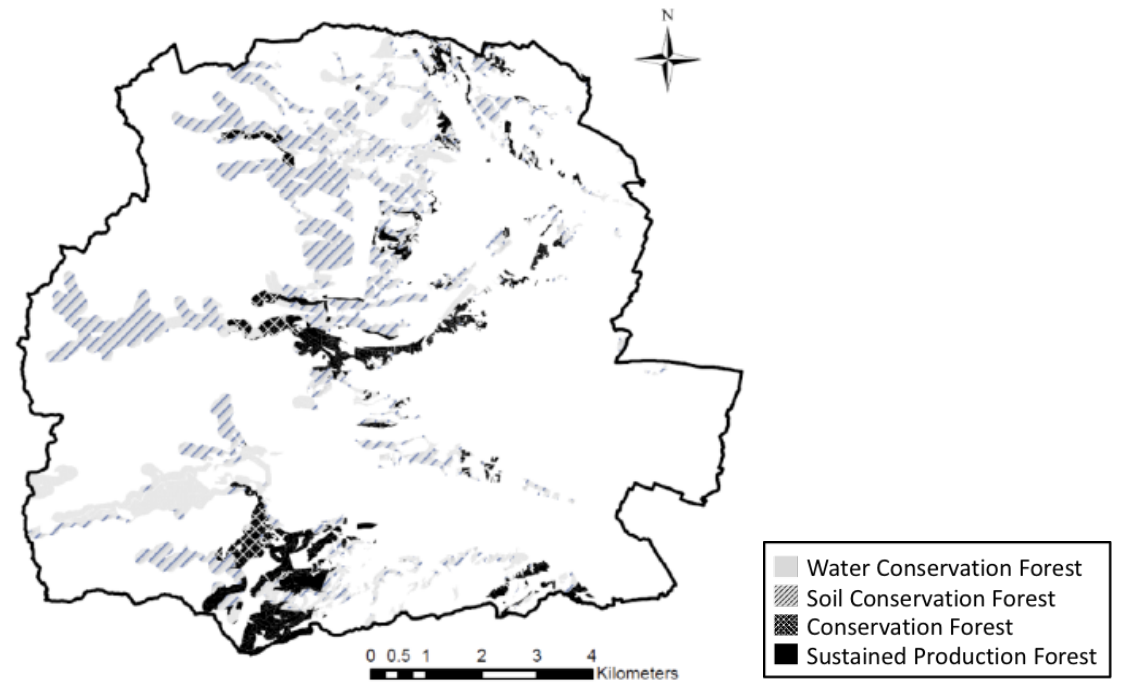

Figure 5. Result of zoning system.

\subsection{Future research}

The forest function evaluation and zoning methods employed in this study can easily and rapidly be used to generate results because they use only the forest registry as analytical data and "mechanical analysis". On the other hand the selection of the evaluation standards and the process of the zoning system are nonsystematic in approach or do not have a single focus objective, in some parts. Therefore, various viewpoints are encouraged, if there is to be advancement in the development of a better approach in this new research area.

In order to evaluate the forest functions more objectively, the process of the function evaluation needs to consider environmental factors such as geography, geology, and climate, as a foundation of forest structure. For several years, the town of Komono has reported several incidence of pine wilt disease. To ensure proper valuation, researchers are encouraged to carry out evaluation based on "damaged state", through processes such as ground survey and aerial photography, in addition to using data from forest registries (Hirose, 2014). The process of the zoning system resulted in "rambling" forest allocation. Therefore, from the perspective of integrating public functions and 
effective forest management, spatial factors should be taken into account in zoning systems. For instance, using the capabilities of alternative allocation with respect to forest functions (Kohroki, 2003), allows the zoning systems to ensure proper allocation of forest resources as well as connectivity between forests and sites.

\section{References}

FFPRI (2000) Research today No.88, < https://www.ffpri.affrc.go.jp/labs/kouho/mori/mori-88.html> (Accessed 22, November, 2017).

Forestry Agency (1991) Study reports on forest development standards and evaluation measurement (Evaluation method for forest development standards)*, Forest Agency, Tokyo (in Japanese).

Forestry Agency (2007) Protection forest system, <http://www.rinya.maff.go.jp/j/tisan/tisan/con_2.html> (Accessed 22, November, 2017) (in Japanese).

Hirose, Y. (2014) Introduction of local level indicators in sustainable forest management, Mie University: 49pp (in Japanese).

Hokkaido (2006) Forest function evaluation criteria (Hokkaido), <http://www.pref.hokkaido.lg.jp/sr/s rk/hyouka/standard/index.htm> (Accessed 22, November, 2017) (in Japanese).

Ito, S., Kizaki, K., Mitsuda, Y., Hirata, R., Yamagawa, H. and Saegusa, N. (2013) Zoning of small catchment for restoration of natural forests with special reference to site productivity, soil erosion risks and riparian buffer strip, Japan Association for Landscape Ecology 18(2): 139-147 (in Japanese with English abstract).

Kawata, S. and Matsumura, N. (2006) Forest management system conducted by forest zoning procedure and official support for private forests: Applicability of GIS for Sugi plantation forests in Misugi Village, Mie Prefecture, J. For. Plan. 40(1): 57-63 (in Japanese with English abstract).

Kohroki, K. (2003) A study on technique of the forest zoning, ${ }^{*}$ Forest Economic Research Institute. 55(10): 2-18 (in Japanese).

Matsumura, N. (2014) Reports on forest resources utilization in Komono Town,* Mie University: 40pp (in Japanese).

Tsujiuchi, M (2005) The concept and purpose of forest zoning in Mie Prefecture, Forest Science*. 43: 32-38 (in Japanese with English abstract).

Mie Prefecture. (2014) Forestry Statistics Report, 2014 edition,* Mie Prefecture, Mie (in Japanese).

Ohta, T. (1991) Cherished opinion for forest' s water resources and silvicultural treatment, ${ }^{*}$ Suiri Kagaku. 197: 1-33 (in Japanese).

Wu, S., Minowa, M., Shimada, K., Tsuyuki, S., Hiroshima, T. and Lee, J. (2004) A study of forest function valuation and zoning based on GIS Technique for Asahi forest, Bull. Tokyo Univ. For. 111: 59-83 (in Japanese with English Summary).

Zheng, Y., Nagumo, H. (1994) A forest activity classification method using a geographic information system, J. Jpn. For. Soc. 76: 522-530 (in Japanese with English Abstract).

*Approximate translations by the authors. 